\title{
THIRD VARIABILITY, THE INHERITANCE TYPES AND SEED REPRODUCTION IN PLANTS*
}

\author{
S.I. Maletsky ${ }^{1}$, N.V. Roik ${ }^{2}$, V.A. Dragavtsev ${ }^{3}$ \\ ${ }^{1}$ Institute of Cytology and Genetics of Siberian Branch, Russian Academy of Sciences, \\ 10, prosp. Lavrentieva, Novosibirsk, 630090 Russia, \\ e-mail: stas@bionet.nsc.ru; \\ ${ }^{2}$ Isitute of Bioenergetic Crops and Sugar Beet, Ukrainian Academy of Agricultural Sciences, \\ 25, Klinicheskaya ul., Kiev, 03321 Ukraine, \\ e-mail: sugarbeet@ukr.net; \\ ${ }^{3}$ Agrophysical Research Institute, Russian Academy of Agricultural Sciences, \\ 14, Grazhdanskiy prosp., St. Petersburg, 195220 Russia, \\ e-mail:dravial@mail.ru \\ Received April 25, 2013
}

\begin{abstract}
The G. Mendel's model for hereditary factors (genes) and appeared on its base the genecentric paradigm, which postulates that genes control not only inheritance of simple traits of plants and animals, but determine ontogenesis, morphogenesis and all cardinal tendencies of life evolution, are examined. In the article, it is indicated, that along with the discovery of discrete heredity forPisum sativum L., G. Mendel by fact described, in addition to well-known genotypic and paratypic variability, a one more variability for plants of generaHieracium L., which now is denominated as an epigenetic variability. Analysis of literature permits to evolve the idea, that the real distribution of genotypes is determined not only by the G. Mendel's lows for inheritance, but by structure of genomes (a ploidy) and by a manner of plant seeds reproduction (uniparental or biparental). In particular, the facts about the manner of reproduction of seeds of different species and genera demonstrate, that very often the reproductive characters are difficultly dedicated as mendelian, and their inheritance usually has an epigenetic nature. Distinctions in the manner of reproduction of Pisumseeds (double impregnation) and in Hieracium species (apogamy) illustrate the polymorphism of reproductive strategies of two botanical genera and can not be determined, by no means, by activity of postulated specific «genes of parthenogenesis» or their absence. In our opinion, a partenogenetic development of plants embryos can be attributed to epigenetic variability, and it is determined by receiving the external or internal signals, which make the switch from one development program to another, by cells of embryo sacks or seed buds of flower. A lot of manners for seed reproduction in many plant species (Beta vulgaris L., Cannabis sativa L., Rosa canina L., and Fragaria L.) illustrate both likeness and distinction in their hereditary systems. In the article the main role of the Soviet (Russian and Ukrainian) biologists in settling the new (epigenetic) paradigm of development and inheritance is demonstrated.
\end{abstract}

Keywords: mendelism, genocentric paradigm, principle of Astaurov, epigenetic heredity, uniparental and biparental mode of seed reproduction.

I questioned N.I. Vavilov - why splitting of hybrids between spring and winter wheats results in anything but Mendelian 3:1. "This must be just so, - answered Nikolai Ivanovich, -

$3: 1$ is a banality; in more complex crosses, as a rule, must occur more complex ratios". S.P. Zybina. Teacher for Life ("Priroda", 1987, vol. 10, p. 105).

Methodology of biological science of the $20^{\text {th }}$ century is based upon the gene-centric paradigm (GCP) according to which genes control not only single simple traits in plants or animals, but they also determine the whole process of individual development from birth to death. GCP postulates that changes of genes (mutations) and genetic recombinations are responsible for major trends in life's evolution on Earth. Moreover, there's a particular point of view that "the basic unit of selection is not a species, a group or even, strictly speaking, an individual. The main unit is a gene" $(1$, p. 243). GCP is comparable with geocentric paradigm of a solar system prevalent in people's mind before Copernicus.

The idea of genes as a primary force in ontogeny, as well as in evolution of life, was established so long ago and then so often repeated that now it's almost forgotten - this was just a hypothesis. In recent years, it was suggested that "omnipotence of genes is a popular metaphor in the scientific community" (2, p. 46). Along with it, there is a very reasonable opinion that the unit of selection is not a gene (3). Some authors highlight the dramatic situation in post-genomic era of biology conditioned by many factors including GCP. Living cell is a dynamic and very labile system that includes not only genes and chromosomes in the cytoplasm, but also many thousands of proteins and immense small molecules interacting with each other in ways not associated with genes. Understanding the basics of life should cover not only the activity, combinatorics and variability of genes and traits, but also the processes occurring in functional modules of cells (4).

The view of GCP on a sole role of genes in development of features and characters, as well as various assumptions about real or imaginary opportunities of genes in control of life's diversity and evolution appeared simultaneously with the birth of genetics (the beginning of the $20^{\text {th }}$ century). However, GCP is essentially poor correlated with intrinsic properties of genes, which are polymeric nucleotide sequences. Expression of genes is not the result of their autonomous activity, but the effect of physical and chemical signals from outside of the cell and inducing firstly regulator genes and then structural genes. In other words, genes act only as instruments activated by external signals; they provide a material implementation of certain functions of the cell. This is the contour framework of multi-level integrative connections between genes in chromosomes and cytoplasmic receptors of internal and external cell membranes, as well as information signals coming from both intracellular and extracellular environment and inducing the development of features and properties of living things in ontogeny.

Many GCP-based hypotheses of genetics known from the early $20^{\text {th }}$ century today directly contradict to actual results of selection and applied genetics. For example, the mechanism of transgressions proposed within GCP $(\mathrm{AABB} \times$ aaBB $=$ AABB $)$ doesn't allow predicting them in breeding work. Hypotheses about mechanisms of heterosis (accumulation of dominant alleles and overdominance) don't allow forecasting the effect of heterosis. Breeding for heterosis is truly the way of "trial and error", although breeding of hybrid vigor is a key method for improving productivity of all crops. Modern biometric genetics based on GCP and the hypothesis of polygenic nature of productivity traits still haven't become useful for breeding technologies.

Currently, there are actively developed epigenetic researches (epigenetic paradigm of inheritance - EGP) (5) used as a basis to prove epigenetic nature of transgressions (6) and heterosis (7), and develop methods for their prediction. Thus, the earlier described vernalization genes were found to be epigenetic phenomena not associated with any specific loci of DNA nature $(8,9)$.

It is quite possible that new revision of original Mendel's experiments with semantic and semiotic approach will help to re-

* The work was performed under financial support of grants from the SB of the RAS and the NASB № 3 (2012-2014), RFBR №№ 12-04-900000-Bel_a, 13-04-90403. 
vise basics concepts about the nature of genetic factors and their real or mythical role in inheritable determination of characters in plants. Modern view on the nature of heredity facilitates understanding the connections between hereditary variation of traits and diversity of genes and their combinations, as well as the structure of genomes (ploidy) and reproductive systems of botanical species.

In the middle of the $19^{\text {th }}$ century, G. Mendel first enunciated the idea of discrete factors (genes that control development of characters in plants), although his observations were not always unambiguous in phenomenological sense, because objects of his experiments had various systems of seed reproduction. Plants have two types of reproduction (monoecious and dioecious) that uniquely define inheritance of characters in offspring. Uniparental reproduction is considered by many as normal Mendelian trait while actually it isn't, because this is a process, or stage, of ontogeny. This must be mentioned viewing Mendelian laws of inheritance, since the patterns of diversity in offspring at uni- and biparental reproduction are close or almost indistinguishable.

Her e d i y. Heredity at the cellular level is commonly understood as the property of cell nuclei and intracellular compartments to provide structural and functional succession of adjacent generations ("every cell is descended from another cell"). Heredity at organismic level is replication of parental characters in progeny ("like begets like"), which is realized through systems of biochemical reactions, morphogenetic and physiological processes occurring in particular cells, as well as in a whole organism. "The law of hereditary transmission is that each plant or animal reproduces an offspring kin to itself whose similarity rather concerns a general structure than individual features. Wheat produces wheat, and each developing organism acquires the shape inherent to a class, order, genus, and species to which it belongs. That's how heredity is primarily manifested" (10, p. 173).

Variation is "the presence of hereditary or non-hereditary differences in cellular structures (intra-individual variability), between individuals of one population (individual variation), or whole populations (group variation)" (11, p. 501). Hereditary (genotypic) variation is the result of mutations in genes and their combinations, which finds expression in crosses; non-hereditary (modification or paratypic) variation occurs due to external conditions and it is not strictly fixed in the genotype. "Heredity is manifested in both maintenance of conservative traits and preservation of changes, though the latter is observed not in all cases; revealing these cases is one of the most important tasks for modern science of heredity" $(12$, p. 165).

In the $19^{\text {th }}$ century, Ch. Darwin determined two types of variability - undefined (later denoted as genotypic) and specific (now known as paratypic; includes environmental, or modification, and metameric variability). These two types have been engrained in the conceptual apparatus of modern genetics. R. Fisher in the early $20^{\text {th }}$ century proposed the fundamental equation describing variation of quantitative traits: $V_{p h}=V_{g}+V_{e}$, according to which phenotypic variance of a trait is the sum of genotypic and paratypic variances (13).

Heredity is inseparably linked with reproduction, i.e. procreation of new individuals performed through cell cloning, or sexual process, which provides succession and continuity of life. In plants, biological inheritance through sexual reproduction includes processes occurring in individual molecules, cells, and tissues, as well as morphogenetic changes in a whole body. Plants have three systems (three types) of seed reproduction - self-doubling, splitting (division of a whole into two parts), and reproducing. Obviously that each type of reproduction has its specific nature of inheritance and variation.

Cell division starts with self-doubling of DNA molecules, chromosomes, subcellular organelles (chloroplasts and mitochondria) in the cell nuclei and cytoplasm; the completion of self-doubling is usually followed by division (split) of the cell as a whole into two parts through mitosis (division of the nucleus and chromosomes by intracellular spindle) and cytokinesis (formation of a septum between the new cells and their subsequent isolation). Self-doubling of DNA molecules, chromosomes, and intracellular organelles is the expression of the first form of inheritance (structural heredity) when the doubled polymeric molecules and intracellular structures are exact copies of parent molecules and intracellular structures. Mitosis and cytokinesis enable the second type of heredity (cellular heredity): in this case, resulting cells may fully replicate a parent cell or not (e.g. asymmetric division), which may occur without any exact distribution of organelles between daughter cells. The first two types of reproduction can be observed in all members of the plant kingdom capable for both vegetative and sexual reproduction, while the third type (reproduction by seeds) associated with generational change is performed only through sporogenesis and sexual processes in plants (14). Seed reproduction is associated with change of developmental phases (sporophyte $\rightarrow$ gametophyte $\rightarrow$ sporophyte). Gametophytes (mega- and microspores) of plants develop on a sporophyte; they produce a new generation of sporophytes (seeds) through biparental (double fertilization, zygotic embryogenesis) or uniparental reproduction (parthenogenesis, apozygotic embryogenesis). Apparently, these types of seed reproduction predetermine the proportion of genotypes in progeny of seed (flowering) plants.

Mendel's theory of heredity in plants. The development of ideas about the nature of heredity was definitively influenced by hybridization experiments of G. Mendel on pea (Pisum sativum L.) that inaugurated the change of the paradigm of continuous inheritance for the paradigm of discrete inheritance (15). According to Mendel, discrete characters of pea are controlled by specific cellular factors (genes). "The genius of Mendel amazingly clearly and demonstratively showed in his experiments that certain hereditary traits behave independently in crosses as they are freely combined in offspring following probability laws in certain numerical ratios. He proposed the method for investigating the most intricate biological phenomena that earlier had been irresoluble for naturalists of the last century" (16, p. 98). "Experimental exploration of hybridization phenomena leads to discovery of certain regularities. Thus develops the experimental science about heredity and variation - genetics. A significant part of this science is defined by studying hereditary features of living things using the method of crosses and detailed inspection of progeny. This branch of genetics originated from Mendel's works was named after him as "mendelism" or Mendelian genetics. It's another frequent name is factorial genetics, because its task is identification of genes - hereditary factors determining particular characters of living things" (16, p. 103).

Mendel's idea of discrete hereditary factors was confirmed by numerous experiments on both plants and animals, which has provided its wide support among biologists (15). Mendelian paradigm also has found a logical confirmation and completion in 19111915 in the chromosome theory of heredity enunciated by Th. Morgan (chromosomes - carriers of genes), and in the mid-1950s with discovery of the chemical code of DNA molecules. This allowed to change the abstract concept of "factor" (gene) for real data about information sequence of nucleotides in DNA molecule. According to the central dogma of molecular genetics, double-stranded DNA molecules serve as a template for synthesis of messenger RNA that, in turn, act as a template for synthesis of polypeptides - components of protein molecules that are a construction material for restoration of basic cellular structures and maintenance of various functions of the cell.

Long before the discovery of information storage property of DNA, Mendelian analysis allowed the experimental study of genetic variation in hybrid generations - segregation of characters associated with spontaneous or induced mutations. Mutation is "any change in structure or composition of DNA (in sequence of nucleotides, chromosomes, genome) occurred spontaneously or induced by mutagens. Mutation leads, or not leads (silent mutation), to changes in some traits of an organism" (17, p. 559). Mendelian 
vision of heredity is probabilistic in nature and considers a plant as a biomorph composed by many discrete characters (phenes). Mendelian paradigm (GCP) usually assumes that each feature (phene) is controlled by one or more (sometimes many) factors (genes) of the genome. Postulated unambiguous relations between genes located in chromosomes and individual's characters allowed introducing algebraic symbols for genes, using probabilistic rules of addition and multiplication, calculating the frequency of genes, genotypes, and phenotypes in progenies, describing segregated traits in hybrid generations, etc.

Is it possible that genotypic variation (variation between phenotypes in perfectly identical conditions of growth) in seed progenies of plants is associated solely with "commands" of specific genes or mutative changes in DNA molecules, and it has no any other nature? It is worth recalling that in the early $20^{\text {th }}$ century some founders of genetics $-\mathrm{H}$. De Vries, C. Correns, W. Batson, etc. upheld the idea about not one but two systems of inheritance - Pisum type and Hieracium type (15, 18). Now it is clear that they differ not in structure of DNA molecules and peculiarities of mitotic and meiotic cell divisions, but in type of seed reproduction peculiar to different plant species.

A subsequent development of knowledge about the nature of heredity and variability showed that, along with these two types of variability (genetic and paratypic), there is a third type - epigenetic variability; it is manifested in morphogenesis of animals (19) and reproductive strategies of plants (14). Epigenetic modifications are modifications in the genome and plastome of cells not associated with changes in DNA sequence. Frequency of epigenetic changes is always several orders higher than the frequency of genetic (mutative) changes (20-23).

Heredity of Pisum type. Facts about transfer of discrete characters in several generations of pea (Fig. 1) and some other plant species were so convincing that allowed formulating three laws of Mendelian genetics. The first law postulates uniformity of the first generation hybrids $F_{1}$, or the law of dominance: the cross between two homozygotes results in $F_{1}$ hybrids with uniform genotype and phenotype; gametogenesis in heterozygotes leads to formation of gametes with equal probability carrying one of the two factors (alleles) determining a trait. The second law is the law of segregation: a cross between two $F_{1}$ plants or self-pollination of $F_{1}$ results in offspring including about a quarter of individuals carrying a recessive trait (Fig. 1). The third law is the law of independent inheritance of individual traits $(24$, p. 390).

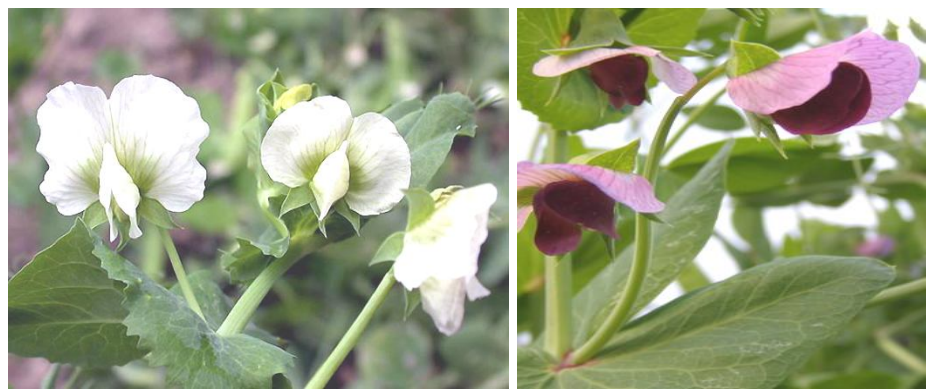

Fig. 1. Two forms of pea with alternative color of flowers (inherited with monogenic pattern)

Along with pea, Mendel also experimented on beans; he noted that "...numerical ratios in which different forms occurred in individual generations were similar to those of Pisum" (24, p. 34). He clearly understood that traits manifested in different hybrid generations of $P$. sativum L. were nonrandom and he discovered fundamental laws of inheritance; willing to show the validity of these laws in new plants species, Mendel tried to expand the range of test objects for hybridological analysis.

Inheritance of Hieracium type. Searching for new objects of study, Mendel investigated about 20 plant species. Many of them later became classical objects of genetics - Antirrhinum, Melandrium, Lychnus (Silene), Mirabilis, Zea mays, etc. (18). Mendel's attention was focused on hawkweed (Hieracium L.) - one of the most polymorphic genera in the world flora including about 15000 species. Its most ordinary representatives are $H$. pilosela L. - a common plant in the European part of Russia growing in arid regions, pine forests, pastures, along roads, etc., and $H$. umbellatum L. - a large plant up to $120 \mathrm{~cm}$ height with $1-140$ anthodia in peltate-paniculate inflorescences (25). This genus has a "bad repute" among botanists for its incredible diversity. Mendel supposed that experiments on Hieracium species would confirm the laws of heredity earlier discovered by him on Pisum. Mendel tried to reveal the inheritance of the color of anthodia in Hieracium performing the following crosses (26) :

H. auricula $(2 \mathrm{x}=18) \times$ H. aurantiacum $(2 n=4 \mathrm{x}=36 ; 5 \mathrm{x}=45)$,

H. auricula $(2 \mathrm{x}=18) \times H$. pilosella $(2 n=4 \mathrm{x}=36 ; 5 \mathrm{x}=45 ; 6 \mathrm{x}=54 ; 7 \mathrm{x}=63)$,

H. auricula $(2 \mathrm{x}=18) \times H$. pratense $(2 n=4 \mathrm{x}=36)$,

$H$. echioides $(2 n=4 \mathrm{x}=36) \times H$. aurantiacum $(2 n=4 \mathrm{x}=36 ; 5 \mathrm{x}=45)$,

$H$. praealtum $(2 n=5 \mathrm{x}=45) \times H$. flagellare Rchb. $(2 n=4 \mathrm{x}=36 ; 5 \mathrm{x}=42)$,

$H$. praealtum $(2 n=5 \mathrm{x}=45) \times H$. aurantiacum $(2 n=4 \mathrm{x}=36 ; 5 \mathrm{x}=45)$;

in parentheses - number of chromosomes and genomes in the nuclei of cells (27, p. 111). Mendel was surprised to find that the color of anthodia in Hieracium hybrids was inherited in the way distinct from patterns peculiar to P. sativum; thus it was revealed an unexpected but obviously important fact of modern biology: the laws of inheritance acceptable for one plant genus may be unsuitable for other genera. The expression of color and morphology of anthodia in hybrid hawkweeds had become a real puzzle for Mendel and made him to realize that Pisum and Hieracium have different laws of inheritance, although the nature of these differences remained unknown to him $(15,18)$. Actually, results of his observations of these two genera were diametrically opposite: interspecific $\mathrm{F}_{1}$ hybrids of Hieracium manifested unconceivable patterns of splitting in crosses similar to the previously performed on Pisum; however, $\mathrm{F}_{2}$, on the contrary, were homogeneous and didn't split, which Mendel also couldn't understand (Fig. 2). 


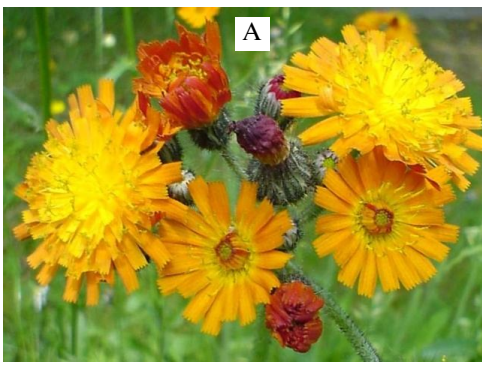

Fig. 2. Phenotypic diversity in color and shape of anthodia in different Hieracium species (hawkweed) (A) and in $\mathrm{F}_{1}$ hybrid (Hieracium auricula $\times \mathrm{H}$. aurantiacum) (B) (cited from 28).
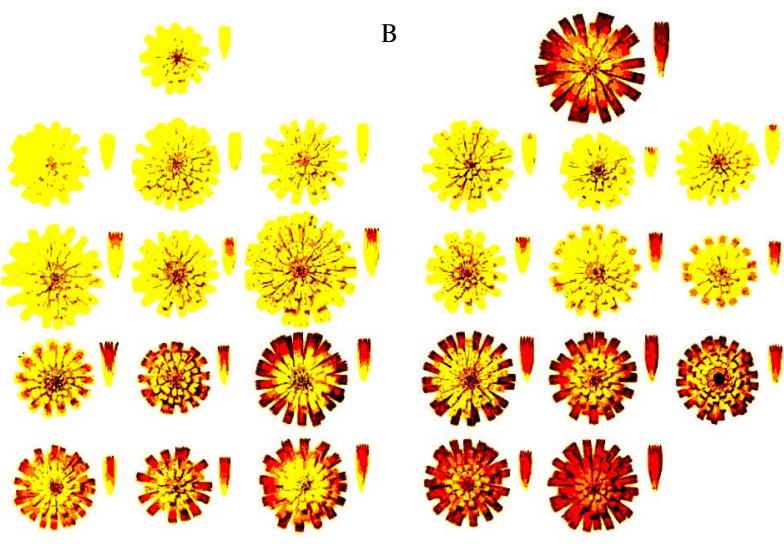

The hybrid $H$. auricula $\times H$. aurantiacum was one of the variants of crosses conducted by $\mathrm{G}$. Mendel $(15$, 18). According to preliminary observations, Mendel believed that both parent species were phenotypically homogeneous, i.e. fully homozygous. Later, this cross was reproduced by Danish botanist C.H. Ostenfeld (28) (Fig. 2, B); investigating one of its largest progenies, it wasn't found in $\mathrm{F}_{1}$ generation any two plants with similar phenotype for color and size of anthodia. Only in the early $20^{\text {th }}$ century this phenomenon was unriddled: differences in inheritance of traits in pea and hawkweed are not linked with discrete hereditary factors, but with differences in reproductive biology of these plant genera. Peas has biparental type of seed reproduction: embryos develop from zygotic cells after fusion of the ovule and sperm cells of a pollen tube (double fertilization); hawkweed is one of many angiosperms whose embryos may develop through both biparental and uniparental (parthenogenetic) reproduction $(26,28,29)$.

Parthenogenesis is a so-called virgin reproduction, or development of an embryo from the egg without fertilization. It was first described by Swiss naturalist Ch. Bonnet in XVIII century. He reported that common aphids in summer are usually represented only by wingless females that give birth to live young. In autumn, male aphids occur among the females. Fertilized eggs overwinter to hatch with winged females that fly on feeder plants and establish new colonies of wingless parthenogenetic females. A similar developmental cycle was observed in many insects, small crustaceans - daphnia, and microscopic aquatic animals - rotifers. In some species of rotifers and insects it wasn't found any males, a sexual reproduction is completely absent, and their populations include only parthenogenetic females (http://ru.wikipedia.org). Some reputable scientists assume parthenogenesis as a form of sexual reproduction widespread among many groups of living creatures (insects, fish, plants), others believe that parthenogenesis is asexual reproduction (authors of this work don't uphold this view). It is important to note that parthenogenesis is not one of many alternative features of some particular species, but the variant of development, one of the ontogeny stages including one (or more) parthenogenetic generation(s) of individuals (seeds) formed within a cycle of sexual reproduction of individuals (seeds). There are various forms of parthenogenesis occurring in both animals and plants; in plants, parthenogenesis is even more frequent than in animals $(29,30)$.

Parthenogenesis of plants was first described in the $19^{\text {th }}$ century in Alcornea illcifolia. This dioecious plant has pistillate and staminate flowers developing on different individuals. In the Botanical Gardens of Kew near London were planted only pistillate individuals that brought a surprise to botanists in 1839 with a bountiful harvest of seeds. Today it is known that many members of Compositae and other families - Poaceae, Rosaceae, Cruciferae, etc. (many cultivars of raspberry, common dandelion) produce parthenogenetic seeds (30, 31). N.A. Kholodkovsky wrote: "Parthenogenesis is a special way of sexual reproduction performed only by females without fertilization. Who would have thought that such an ordinary plant as dandelion reproduces itself parthenogenetically? And the evidence of missing fertilization here is received with deep distrust" $(32$, p. 351). Parthenogenetic reproduction of seeds in plants is named by different synonymous terms apogamy (apomixis), agamospermy, apozygoty (33).

C. Ostenfeld conducted experiments with castration and hybridization of hawkweeds $(26,28)$ (Fig. 2), many of which, as noted above, have parthenogenetic embryogenesis; his targets were, on the one hand, investigating features of seed reproduction and, on the other, repeating Mendel's crosses of the 1860ies. Ostenfeld wrote: "I performed observations of many species (about 65) and found that most of them are apogamous. Only two species, H. umbellatum and $H$. virgaauren, need fertilization to produce seeds and do not form seeds after castration. Nevertheless, one of the apogamous forms of $H$. umbellatum produces some seeds after castration, if compared with intact flowers. Several other species are likely to be only partially apogamous comparing the number of seeds in castrated and non-castrated flowers. Thus, we see three stages in development of apogamy: 1) sexual species, 2) partially apogamous species, 3) totally apogamous species" (26, p. 347). As a result, it was shown that seeds in hawkweed can develop through uniparental as well as biparental mode (18, 28). In parthenogenesis, initial cell for a new embryo may be cells of the embryo sac (gametophytic apozygoty) or somatic cells of the nucellus (somatic apozygoty).

One of the most intriguing questions in the history of biology - whether G. Mendel was aware about the existence of uniparental seed reproduction in plants? He possibly was. The article of J. Smith (34) about parthenogenesis in A. illcifolia could be unknown personally to G. Mendel, a "botany enthusiast" as he modestly signed his articles. However, experimenting on hawkweed, Mendel consulted the professor S.W. Nägeli from Munich who was a notable European botanist at that time. It is very likely that Nägeli knew about observations of J. Smith, although this wasn't reflected in his correspondence with Mendel. 10 letters of Nägeli to Mendel were later published in scientific journals, and they don't mention the work of J. Smith about parthenogenesis in plants (35).

Mendel, the enthusiast of botany, was probably mislead by his conviction that hawkweed and peas, as well as any other plant species, reproduce similarly, i.e. produce seeds through pollination of flowers and completed fertilization. Flowers of hawkweed really form both mega- and microspores, as well as abundant pollen grains in anthers, but it was quite hard to find out that these pollen grains do not participate directly in formation of a new generation of seeds.

Another complication in Mendel's research was the fact that the genus Hieracium in nature is represented by a variety of highly polyploid species. This fact was discovered by O. Rosenberg only in the beginning of the $20^{\text {th }}$ century (36), and later among hawkweeds were identified di-, tri -, tetra-, penta -, hexa - and heptaploid species (27). Cytological studies of O. Rosenberg and other authors had initiated the idea of polyploidy and parthenogenesis in plants as interconnected phenomena $(30,31,36,37)$.

Polyploidy (increased number of chromosomes or chromatids in the nucleus multiple to the basic set) leads to a multiple repetition of homologous chromosomes or chromatids and completely changes proportions of genotypes and phenotypes in hybrid offspring (38); this is one of the variants of intragenome variability, although the polyploidy itself doesn't introduces any changes into the sequence of nucleo- 
tides in DNA molecules. In nature, even polyploidy is the most frequent: tetra-, hexa-, octaploidy, etc. Odd polyploidy is less common: tri-, penta-, heptaploidy. Transition to a higher ploidy level changes the ratio of genotypes in hybrid progenies (polysomic segregation of genes) (38) and changes many morphological and physiological characteristics that has long been widely used in plant breeding (39). This type of variation in plants can be considered as one of the most common forms of epigenetic variation in nature $(14,40)$.

Modern scientific view on results of Mendel's experiments on hawkweed shows that they couldn't overturn his concept of discrete hereditary factors in P. sativum. The problem should be named otherwise. Firstly, whether there are any specific hereditary factors (genes) that cause parthenogenetic seed reproduction in plants (in particular, hawkweed) being also subject to segregation, such as color of flowers in pea? Secondly, could segregation for "parthenogenesis genes" affect segregation for color of anthodia in Hieracium or not, and, therefore, provide the opportunity for an experimenter to manipulate with "parthenogenesis genes" and transfer them to other species through interspecific or intergeneric hybridization?

According to GCP, all traits and properties of plants are controlled by genes, so there must be the genes for parthenogenesis as well; this hypothesis is supported by many scientists $(31,37)$. Moreover, the expected success in transfer of apomixis genes between plants of different species may provide the new wave of "green revolution" in agriculture anticipated in the $21^{\text {st }}$ century (41-43). However, such works haven't yet yielded any successful cases of interspecific gene transfer.

Genetic control of apogamy (apomixis) is discussed by many authors who describe apogamy as one of numerous discrete genetically determined traits of plants and support it by references to specific studies of this subject $(37,41-45)$. This allows a directly formulated task for practical breeding and genetics: since wild plant species have genes of apogamy (apomixis), it's just a matter of time to transfer them to crop species by means of genetic engineering, because modern biotechnology, as we know, "may almost all" $(11,41)$.

At the same time, genes of parthenogenesis are almost unknown for zoologists, primarily because they consider parthenogenesis not as a discrete trait controlled by Mendelian genes but the process or ontogeny stage of species with cyclic type of sexual process. Parthenogenetic development of embryos doesn't start with activation of "parthenogenetic genes" in their genomes, but with stimulation of egg development. "Activation is the start of egg development. It can be caused by various agents. One of them, the most natural, is the sperm [not merging with the egg, but only activating it - authors' note]. Without egg activation there is no development; without the sperm this may occur [due to other activators - authors' note] in nature, as well as in the experiment" (17, p. 3). Entomologists haven't yet sought any genes for parthenogenesis in aphids, because their parthenogenetic reproduction is associated with seasonal oscillations in air temperature. This process is considered as uniparental reproduction that occurs along with biparental reproduction in aphids and other insects (29, 46, 47). If plants, probably, have no structural genes of parthenogenesis (apogamy), this changes the task of experimentation: not "infecting" the crops with these "mythical" apogamy genes transferred from wild forms $(11,41)$, but selecting the signals that initiate parthenogenetic development of cells in reproductive structures of cultivated plants (44) or animals (46).

Considering parthenogenesis as a special form of sexual reproduction, it mustn't be seen just as evolutionary dead end that only fixes (clones) a previously accumulated variation. Parthenogenetic progeny exhibits an obvious genetic diversity of both discrete and continuous traits. The founder of the national genetics Yu.A. Filipchenko wrote with a certainty: "The marked theorist of heredity Weismann [A. Weismann - hereinafter editor's notes] (1874) had long ago suggested the idea that variation is largely determined by mixing of genetic substances of both parents during fertilization. The validity of this assumption could be verified only by special statistical studies that have been conducted much later. However, such research, as regarding individual variation, did not confirm that Weismann's assumption; comparing variation of forms resulting from parthenogenetic reproduction with variation of progeny after sexual reproduction, it wasn't found any specific distinction between them. Similar studies were performed by Warren on daphnia and aphids, W.E. Castle and E.F. Phillips - on drones and workers of a honey bee, by C. Pearson, C.C. Li, and S. Wright - on wasps, by W.E. Castle et al. - on flies Drosophila ampelaphila, Walton - on algae Spirogira inflata ; all these cases had similar results disaccording with the idea of A. Weismann. For example, in daphnia, parthenogenetic individuals showed even higher variation than the progeny produced through sexual reproduction; in wasps, the highest diversity was observed among workers (the progeny after sexual reproduction), then - males (result of parthenogenesis), and finally, the lowest variation was found in females (result of fertilization). Thus, contrary to Weismann's assumption, it should be admitted that the origin from fertilized or unfertilized eggs, i.e. mixing or not mixing of various hereditary substances, does not affects individual variability" ( 47, p. 2930).

The third variation. Different plant species have different modes of seed reproduction, which means that experimenters will find various distribution patterns of genetic material in several generations leading to different splitting patterns of particular traits, and, in some cases, the absence of splitting. This was the phenomenon observed by G. Mendel in his hybridization experiments on Hieracium in 1860; most of those findings were associated with epigenetic variation rather than genetic diversity.

Let's recall some works associated with epigenetic paradigm (EGP) of inheritance of characters. G. Kekser (48) in 1960 showed that switching of biogeochemical cycles in the presence of catalysts' hierarchy causes phenotypic performance with discrete variation corresponding to so-called Mendelian genes. A. Durrant in 1962 described genetrophs in flax (23), while E.D. Bogdanova identified nicotinetrophs in wheat $(20,21)$. T.B. Batygina demonstrated epigenetic nature of variation of embryonic developmental stages in plants (49); she showed that, depending on the origin of embryos, in plants may occur different types of seeds: with sexual (zygotic) embryos (biparental inheritance); with hemigamous chimerical embryos (bi- and uniparental inheritance); with parthenogenetic embryos (maternal or paternal uniparental inheritance) - diploid (unreduced parthenogenesis), haploid (reduced parthenogenesis or reduced androgenesis); with embryoids (uniparental inheritance) - nucellar, integumental, monozygotic. V.A. Dragavtsev et al. (50) in 1984 had discovered the change in spectra and number of genes determining productivity traits of wheat caused by the change of environmental factors, which later was proved on a comprehensive material (6). EGP was used by S.I. Maletskii et al. (7) who in 2013 examined epigenetic nature of heterosis in plants, particularly, sugar beet. In domestication experiences of D.K. Belyaev et all. it was described the new phenomenon of destabilizing selection whose mechanism was unclear at that time. Later, E. Jablonka and M. Lamb analyzed these experiments with modern attitude and revealed hereditary variation of epigenetic nature in behavior of silver foxes and other wild animals (51). S.V. Savel'yev in 2012 described 13 new substages in normal development of human brain and more than 200 cases of violations in its functioning in embryos (52). It was found that the earliest stages of brain formation don't much depend on genes but rather depend on interactions of cells to each other.

Currently, there are numerous examples showing epigenetic variation and epigenetic inheritance of traits in plants and animals. They all belong to the phenomena of so-called "non-canonical genetics" (more properly - non-canonical inheritance): these are long-lasting modifications, genetic assimilation, genomic instability caused by mobile genetic elements, paramutations, parental imprinting, horizontal transfer of genes, reverse transcription, epigenetic sex determination, properties exhibited by prions, inactivation of X-chromosome, and even "heredity of signaling" according to M.E. Lobashev. However, a coherent view on EGP is being formed just nowadays. M.D. Golubovskii specified two subsystems of elements within the genome - obligate (genes and their regulators in chromosomes and organelles) and 
optional (different DNA- and RNA-carriers that occur in cells with various amount and topography) elements; he proposed the typical triad of epigenetic regulation: signal $\rightarrow$ signal perception by switching locus $\rightarrow$ maintaining of a selected state (53).

The discovery of epigenetic variation has a long history starting from, in the authors' opinion, works of Russian biologists B.L. Astaurov and N.V. Timofeev-Resovskii. They first discovered the third type of variation, the phenomenon named by different scientists as "asymmetrical" or "accidental" (19, 54), later - as "autonomous"(55), "realizational" (56), and, finally, "epigenetic" variation (57).
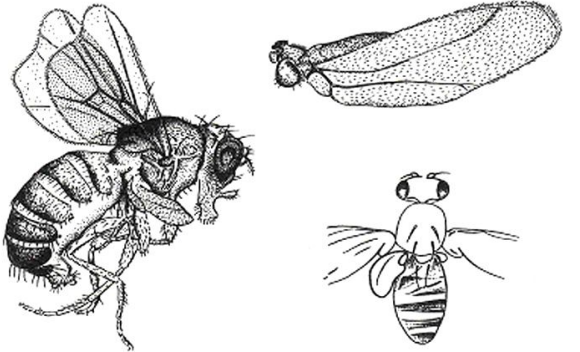

Fig. 3. Mutation tetraptera in Drosophila melanogaster - the example of asymmetrical inheritance of "four winged" trait in insects $(19,55)$. the lines with radius incompletes there were the lines showing dominance in crosses with both normal lines L5 and KII, as well as those that dominated in crosses with only one of them" $(55$, p. 49).

Experiments of Timofeev-Resovskii were complemented by B.L. Astaurov $(19,54)$ who investigated tetraptera mutation in D. melanogaster and demonstrated independent expression of phenotypes occurring apart from genotypes. Comparing the expression of the mutant trait on left and right body sides of flies, Astaurov concluded that asymmetric inheritance of tetraptera mutation is the result of independent variation caused by internal conditions of development that can't be explained only by genetic or environmental conditions. "Genetic variation of tetraptera $(t r)$ is recessive. While present in a homozygous state, this factor causes quite diverse changes of halters, and in some cases transforms them into real wings. Statistical analysis of variations of this phenomenon leads to the amazing conclusion about independent variation of this trait on different body sides" (54, p. 54). "Variations of individual development not reducible to genotypic differences and direct action of the environment is, in opinion of Timofeev - Resovskii (1925), the reason of incomplete manifestations of the genetic variation of radius incompletus in Drosophila funebris. Plankett (1926) holds to the same view on asymmetric expression of Diacheta trait in D. melanogaster - the phenomenon commonly similar to the asymmetry of $t r$ " (54, p. 58). Asymmetric variation of homozygotes in the literature is often called as "Astaurov principle of inheritance" (55-57).

Explaining the nature of this new type of variation, Astaurov used the following logic. Formation of mutant phenotypes in flies he described by a standard formula: $a=F(p, g, e)$, where $p, g$, and $e$-contributions from, respectively, cytoplasm, genotype, and environmental conditions in manifestation of a trait. In the mutant flies all the three factors were identical, so they can't explain the nature of variation observed by Astaurov. "Regarding a particular case - variation of halters in homozygous cultures ( $t r)$ - let's question ourselves - instability of which of the three factors $(p, g, e)$ caused variation of this trait? The first asseverated thing is the absolute exclusion from this variation of the direct effects of genotype and environment. The reasonable base of statement is independent expression and manifestation of the trait on different body sides of one individual. Both halves of the flies develop in equal environment, their genotypic conditions are also quite uniform, however, this trait may be expressed on different sides of one body in two extreme forms of variation series, even alternative (presence or absence of the trait). Obviously, there should be some other causes of variation" (54, p. 57).

Asymmetric variation of $t r$ gene is associated with "internal" factors of unspecified nature. "With internal conditions denoted as $i$, the final formula of development is: $a=F(p, g, e, i)$. The particular variation dependant on instability of $i$ factor is independent variability of organs, primordia, etc." $(54$, p. 58). "The main conclusion is that quite many traits of Drosophila have variation not reducible nor to the genotypic variation, neither to the influence of external conditions. This variation is especially distinct in laboratory mutations showing it in the form of partial manifestation, or extremely varying expression. However, this also occurs in normal traits of species that differ from laboratory mutations only in magnitude. In other words, back to the abovementioned conditional denotation of development of an organism or organ, in the case of most constant $p, g$, and $e$ the function $a=\mathrm{F}(p, g, e)$ includes the range of possible values $a_{1}, a_{2}, a_{3}, \ldots, a_{n}$ and this occurs due to variation of some factor $i$ that is necessary to be introduced to the arguments of this function. We see that a seemingly exceptional phenomenon exemplified by genetic variation of tetraptera is actually just an apparent case of a very common regularity. This somewhat reduces paradoxicalness of that "right side doesn't know what the left does" $(54$, p. 72$)$. "Here we see firsthand how unstable are such properties of living things as heredity, symmetry, precise regulation of ontogeny processes, the properties often seen as inherent attributes of the organic world" (54, p. 103).

Recent reports show the cases of principally unavoidable stochasticity in gene expression (58). This may be an important task for future researches to find out whether the hypothetical Astaurov's factor $i$ belongs to the abovementioned stochasticity varying from cell to cell, or it is determined by the histone code regulating the expression in many cells affecting a trait.

Expression of mutations tetraptera and radius incompletes in homozygotes demonstrated that GCP (individuals' phenotype is determined by their genotype and the influence of environmental conditions) can't explain the observed variability. These observations contributed to establishing the third variability type by Russian biologists B.L. Astaurov and N.V. Timofeev-Resovskii, which discovery is especially important for the general theory of heredity and selection. "Any morphogenetic process in the organism has some degree of independence, stochastic variation not reducible nor to effects of genotypic differences neither to direct influences of the environment" (54, p. 103). "Astaurov explained incomplete and asymmetric expression of this trait (four-winged) as a result of independent variation irreducible nor to a genotype neither to external conditions" (56, p. 18).

Adequate description of variation for any discrete morphological characters must include both arithmetic and geometric properties of traits, which was brightly performed by B.L. Astaurov (54). This adequacy is realized using the terms "symmetryasymmetry" corresponding to epigenetic (implemented) variation in plants and animals. The literature shows many examples of asymmetric variation of discrete traits. One of the earliest ones was the case described by R. Goldschmidt (1915) - gynandromorphs of Drosophila with one male body half and the other half - female. "In these flies, a longitudinal - sagittal - plane separating the left 
and the right halves of the body, has changed its normal mirror symmetry to unusual dissymmetry" (59, p. 132). "Gynandromorphism of insects is the result of deletion of X chromosome during fertilization of the zygote. A half of the body in these flies is male by the phenotype and a set of sex chromosomes, while the other is female" (60, pp. 111-112).

The evidence of variation in homozygous flies contradicted with Mendel's law for Pisum - the absence of genotypic diversity in progeny of homozygotes, as well as Johannsen's rule - the reduce of phenotypic diversity in progeny of homozygotes (61). The conflict between the new discovered variation type and Mendelian inheritance paradigm suggested the conclusion - Mendelian laws of inheritance are incomplete and necessitate a correction with "Astaurov's rules of inheritance" (along with Mendelian) to be included among the so-called "general laws" of inheritance. However, this didn't happen, and the collision was smoothed just by introducing two new terms - "penetrance" and "expressivity" (62), which don't explain causes and nature of the new variation type. It should be recalled that penetrance is the percentage of individuals - carriers of a specific investigated gene (allele) in which it is manifested relative to the total number of individuals in population $(17$, p. 623), and expressiveness is "the degree of phenotypic expression of the gene as a measure of the strength of its action determined from the degree of expression of a trait. Mutants with incomplete penetrance, obviously, in many cases are especially predisposed to variable expressivity"(17, p. 840).

Asymmetric variation according to Astaurov affects different groups of traits and, as noted above, today it is classified as epigenetic variation $(56,63,64)$. Internal factors of asymmetric development of traits are epigenetic mechanisms of activation and inactivation of both structural and regulatory genes, as well as external signals affecting particular stages of morphogenesis in higher plants and animals. Asymmetric morphogenesis is exemplified by numerous cases of "homeosis" (Bateson, 1894) - abnormal formation of particular body parts that normally should be located on another segment" $(60, \mathrm{p}$. 117). Such teratological disorders are defined as "homeotic, or heteromorphic" mutations; in this case, instead of some normal body part on its site develops some another organ (e.g., Drosophila with mutation antennapedia have on its head a tarsus formed instead of antenna). Investigation of these mutations resulted in the discovery of transcription factors (TF) of morphogenesis (TF - proteins that control mRNA synthesis on DNA template, which operate independently or cooperate with other proteins; repressors inhibit, activators - increase the affinity constant of binding RNA polymerase to regulatory sequences of a controlled gene). In was a homeotic mutation tetraptera in D. melanogaster that allowed Astaurov in 1927 to establish the third variation type - asymmetric variation (54).

A public debate between scientific schools of K. Pearson (inheritance of piebald color in dogs) and N.H. Nilsson-Ehle (hypothesis of polymeric genes in inheritance of quantitative traits; later renamed into polygenes) took place in 1914 in London. At that time N.I. Vavilov worked in Germany at Ernst Haeckel's laboratory; despite of his intention to attend this debate, Vavilov had to to come back to Russia by a circuitous route through Norway, Sweden, and Finland because of the beginning of the World War I. The hypothesis of Nilsson-Ehle wasn't admitted by Pearson's School even though it couldn't explain the inheritance of piebald fur color in dogs. Later, instead of polymeric genes it was proposed another hypothesis of morphogens - carriers of positional information for morphogenesis in tissues of animals and plants that act as activators and inhibitors, and realize their properties through spatial diffusion (65).

Let's consider an example. In an apple orchard all trees are genetically identical clones of one variety; among them there is one tree with the first scaffold branch coming off from the trunk at a height of $50 \mathrm{~cm}$ direct to the south, as well as another tree whose first scaffold branch is located on height of $1 \mathrm{~m}$ being oriented to the east. This is a typical manifestation of "the third variation" of morphological characters according to B.L. Astaurov (54).

It is a common knowledge that morphogenesis occurs in crystals, ice patterns on a windowpane looking like leaves of plants, morphological diversity of snowflakes, dendrites emerging on edges of electrochemical bath during electrolysis of metals, etc. These phenomena show that morphogenetic processes in the broadest sense may be caused by self-organization without a direct control of genes (these cases definitely do not involve any genes).

Classification of traits in plants and epigenetics. A modern concept of the genome assumes it as a specific sequence of nucleotides within a DNA (in some viruses - RNA) determining the nucleic acid sequence of transfer RNA or ribosomal RNA, or the amino acid sequence of proteins (structural genes). As a rule, genes contain leader and trailer sequences preceding and following the coding regions, as well as coding (exons) and non-coding (introns) segments (17, p. 210). GCP definitely discriminates the ideas of "gene" and "trait": the first is the subject of molecular genetics, the second - of general biology. There's a similar distinction between the concepts of "trait" and "process": a trait is any feature or character of a single individual or a group of individuals at a given moment of time, whereas a process is the change of states in time, i.e. a series of consecutive actions leading to a certain implied result, an objective (e.g., plant ontogeny, production process). So, ontogeny is a process in time, while variation of a trait is an instantaneous state in a given moment of time, therefore, variation range of a trait at different developmental stages is always orthogonal to a temporal axis.

GCP classifies all traits as discrete or continuous determinable through measuring parts of plants and whole plants as numerical values related to a common arithmetic or three-dimensional Euclidean geometry. In turn, discrete traits are divided into two groups - alternative and numerable. Alternative traits exist in several states (two or more: color of flowers - white, pink, and red; multiple forms of the enzyme - isozymes, etc.) and, as shown by numerous observations, they are usually subject to Mendelian laws of inheritance. Meristic (countable) traits characterize the number of parts within a plant or an organ (e.g., number of leaves, flowers, inflorescences, seeds, and fruits per plant, number of structural elements of a flower, etc.). Variation of countable traits obeys the binomial law of Quetelet (47). Unlike alternative traits, meristic traits usually show non-Mendelian inheritance (except for taxonomic countable traits specific for a genus or species - these are strictly determined by genes and stably inherited in both metamers and ecological series).

EGP distinguishes special groups of traits - morphogenetic, reproductive, etc. Morphogenetic traits are fractal features formed in morphogenesis of plants and animals and therefore not subject to direct control of genes. For example, fractal characters of plants include peculiarities of the vascular system (formation of xylem and phloem) and the root system, embryonic traits (49, 66). Morphogenetic processes in plants are described with the use of dendroid fractals (66).

The triad of traits (discrete - continuous - fractal) can be characterized by mathematical terms considering their similarities and differences. These traits have a distinct geometric dimensionality $\mathrm{D}$ that can be calculated for any geometric object from the dependence between the increase in size of this object $(\mathrm{S})$ and the increase of its linear dimensions $(\mathrm{L}): \mathrm{D}=\log (\mathrm{S}) / \log (\mathrm{L})$. For a $\operatorname{line} \mathrm{D}=$ $\log (2) / \log (2)=1$; for a plane $\mathrm{D}=\log (4) / \log (2)=2$; for a volume $\mathrm{D}=\log (8) / \log (2)=3$. Unlike Euclidean geometric figures, fractals are geometric objects with fractional dimensionality (67). From a geometrical point of view, discrete traits are one-dimensional, while continuous traits may be one-, two-, or three-dimensional, and fractal traits always have a fractional dimensionality (66). Thus, repro- 
ductive characters of plants may be countable (number of flowers, seeds, fruits per plant) and fractal (embryonic structures of flowers, etc.). Meristic taxonomic characters usually develop under strict control of genes (number of parts and individual elements of a flower). In the other group of numerical traits (number of flowers, seeds and fruits per plant), variation is controlled by external signals (e.g., density of plants in phytocenosis), so they are rather epigenetic. Embryonic traits and related features of embryonic tissues are fractal characters subject to epigenetic control of morphogenesis.

Epigenetics and reproductive biology of plants. Modern biology investigates mainly genetic control systems within GCP, although any protein molecule or any biogeochemical cycle in a cell capable to switchover between two states ("+" or "-") can transfer the information to the next generation of molecules or cells. Such intracellular switchover may lead to epigenetic variation and inheritance.

Development of EGP revealed new phenomena and mechanisms of genetic variation; one of its most remarkable results was the discovery of new features and properties inherited only within EGP. Formation of EGP concept wasn't rapid. In the early $20^{\text {th }}$ century, scientists described long-lasting modifications with gradual attenuation in several generations. In 1927, B.L. Astaurov discovered "the third variation" $(19,54)$. Mechanisms of epigenetic phenomena have been known from quite a long ago - acetylation of histones and methylation of DNA (68). "Histone code" is a set of modifications of histone "tails" on the surface of nucleosomes that can be purposefully changed, subject to selection, and inherited. This is the main epigenetic mechanism that controls activation or deactivation of genes and the transfer of control program from a mother cell to daughter.

In plants, epigenetic variation is associated with modes of seed reproduction and morphogenesis. Apogamous species are of a particular interest for general genetics, because in these species the function of pollen is not necessarily associated with donation of paternal genome and transfer of genes from father to offspring. On the one hand, flowers of apogamous (agamospermic) and related gamospermic species have no morphological differences. On the other hand, pollen grains and pollen tubes in apogamous species may act not as donors of a paternal genome, but as signals (inducers) that activate the start of parthenogenetic embryo development, so it acts as a "sexual partner" (69). The concept of a "sexual partner" indicates that agamic species have a distinct progamic phase of fertilization (pollen falls on pistil stigma of a flower, germinates, but doesn't cause fertilization) and the absence of gametogamic phase (fusion of male and female gametes) although these plants produce quite abundant seeds.

Differences in seed reproduction of pea and hawkweed (respectively, bi- and uniparental inheritance) illustrate polymorphism of reproductive strategies in two botanical genera (15) and they are not associated with activity or inactivity of any specific "genes for parthenogenesis" in Hieracium. The authors believe that development of parthenogenetic embryos is epigenetic form of heredity and variation occurring in embryo sacs or ovules of a flower under the impact of external or internal signals cell that switches one program of development to another.

Botanical literature shows many modes of seed reproduction distinct from those in both pea and hawkweed (70). Possibly, plants can be classified by their reproductive strategies (that may be similar or different from Mendel's pea and hawkweed) that unroll in ontogenesis without the action of any particular oligogenes (or "gene blocks" and, more especially, "gene networks"). Reproductive features and processes are utterly the issues of developmental biology involved in homologous variation of plants described by N.I. Vavilov (71). Such facts doesn't point to any specific genes supposedly present in certain plant species and responsible for control of parthenogenesis, but the differences in developmental programs and individual cycles of sexual reproduction of seeds. This allows the extremely important theoretical question - in which way seed reproduction of plants evolves - genetic (mutation and recombination) or epigenetic way?

Multiple modes of seed reproduction can be briefly exemplified by several known plant species (Beta vulgaris L., Cannabis sativa L., Rosa canina L., and the genus Fragaria L.). They are widely described in the botanical literature, have some similarities with those of Pisum sativum and Hieracium, as well as some evolutionarily developed types of seed reproduction distinct from those in pea and hawkweed. Hybrid progenies of the abovementioned species contain numerical proportions of genotypes not similar to those observed by Mendel in pea. Moreover, experiments on these species show the possibility of experimental switchover between different modes of seed reproduction by changing external or internal signals, i.e. epigenetic regulation of reproduction.

Reproduction of seeds in Beta vulgaris L. $(2 n=18)$. Sugar beet (family Chenopodiaceae) was introduced as a crop at the end of the $18^{\text {th }}$ century by the German physicist and chemist F.C. Achard (72). A common view is that the beet has crossfertilization (biparental reproduction of seeds) $(73,74)$. Numerous observations have revealed that most of plants in beet populations are self-sterile (self-incompatible), i.e. they do not form a zygote after self-pollination. When own pollen falls on the pistil stigma of own flower, it develops a pollen tube whose growth then slows down and doesn't reach the whole length of the pistil even in 8-9 days (74). On the contrary, in cross-pollination, all pollen tubes reach the micropyle and result in fertilization even by the end of the first day after blooming. It is believed that all self-incompatible plants reproduce seeds due the pollen brought from other plants.

Reproduction process in beet can be modified by changing the temperature regime: at $10-13{ }^{\circ} \mathrm{C}$ self-sterile plants become partially autofertile (pseudo-compatibility). To obtain seeds through self-fertilization, the plants were grown before flowering at $12-13{ }^{\circ} \mathrm{C}$ with short periods of increase up to $15-17^{\circ} \mathrm{C}(75)$. The mode of seed reproduction also changes in sugar beet plants grown in highland conditions with moderate average daily temperatures $(67,76)$.

Along with it, sugar beet may develop seeds through apozygotic reproduction: parthenogenesis in this crop was first described in the 1920 s by N.V. Favorskii (77), the scientist of Belotserkovskaya breeding station in Ukraine. Information about parthenogenetic reproduction of beet seeds had long remained unreclaimed for unclear reasons, and the article of Favorskii has been quoted only since 1970s. Ukrainian biologists reproduced his experiments and found in the beet nucellar embryos - extra embryos developed from the cells of nucellus and growing into embryo sacs $(73,78,79)$. Soon these studies were expanded within the Soviet Union and, along with Ukrainian biologists (70), similar studies of parthenogenesis in beet were carried out in Kazakhstan (80, 81) and Russia (82). 


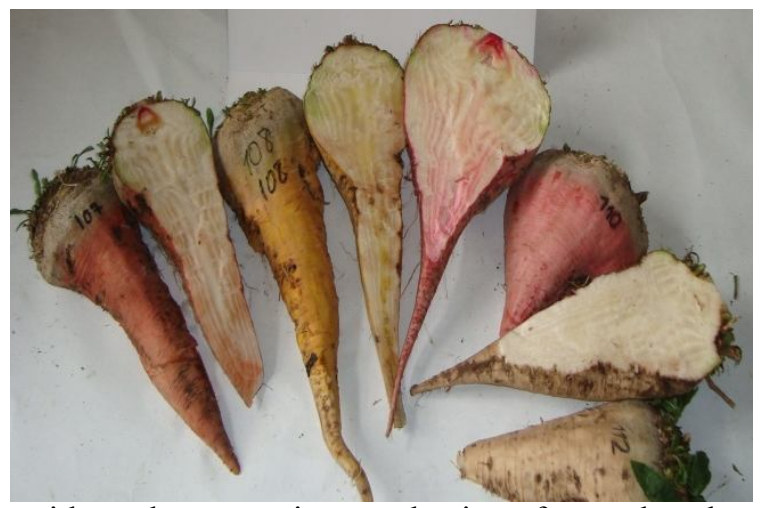

Fig. 4. Epigenetic variation for the color of root skin and pulp in apozygotic progeny of sugar beet (70).

Experiments with parthenogenetic reproduction of sugar beet have changed the view at reproduction of seeds in $B$. vulgaris: it has both uni- and biparental reproduction (83). Today, uniparental reproduction of beet seeds is called parthenogenetic, or pollenless, reproduction. To obtain such seeds, the plants should be grown not as pollen-fertile, but as pollen-sterile in insulators or isolated areas. Obtaining parthenogenetic seeds of beet without pollination has been conducted on large samples reproduced in many generations (83-85). It was noted that pollen-sterile beet plants produce sufficiently high yield of seeds (and even of better quality) through parthenogenetic reproduction (86). It was a quite surprising fact that progeny of pollenless reproduction shows a split for any marker traits (autosegregation) (40, 83, 84, 87-89).

The example of such split is phenotypic diversity in color of beetroot skin and pulp in one apozygotic progeny of a sugar beet plant with white color of the root (Fig. 4). Apozygotic reproduction of seeds in sugar beet is associated with epigenetic changes in the genome. In particular, the maternal plant with white roots produced the progeny with red (pink) or yellow roots. The analysis of autosegregation for root skin color showed that the observed phenomenon was probably the result of activation of $P p$ locus controlling the synthesis of pigments in various beets. Apozygotic progeny manifested activation of this gene, i.e. epigenetic variation (70, 90), which wasn't observed in a progeny of sexual reproduction. In Mendel's experiments on pea, segregation of genotypes for monogenic marker trait looked as the ratio 1AA:2Aa:1aa (or 3:1), but apozygotic progenies of sugar beet exhibited 3AA:8Aa:3aa (or 11:3) (83, 84). Therefore, Beta L. produces seeds in similar ways with both pea (biparental) and hawkweed (parthenogenetic). This may be just one of many cases in a plant world showing diversity in a mode of seed reproduction.

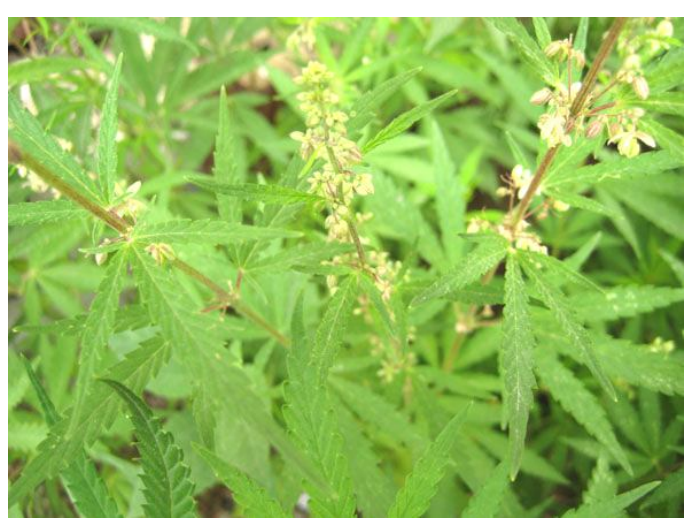

Fig. 5. Flowering hemp plants (Cannabis sativa L.).

Inheritance and regulation of sex in flowers of h e m p (Cannabis sativa L., $2 n=20$ ). Cannabis sativa (family Cannabiaceae) (Fig. 5 ) is a dioecious plant whose individuals develop male or female flowers depending on sex chromosomes: XX-plants form pistillate flowers (maternal), XY-plants staminate flowers (paternal) (in traditional Russian farming - materka and poskon', respectively). "In ordinary hemp fields, the ratio of male and female plants is approximately as $1: 1$, which is believed to be the result of heterogametic state of one of the sexes" (91, p. 7). Normally, hemp has syngamic type of sex determination (chromosomal sex determination during the fusion of male and female gametes), however, epigenetic sex determination is possible as well.

Regulation of flowers' sex in plant ontogenesis is called epigamic sex determination; in this case, karyotypically identical phytomers form staminate or pistillate, or bisexual flowers. "In hemp we observe rapid and diverse changes of a flower under the influence of external conditions. Reduced daylight duration, growing in greenhouse, as well as traumatic injuries cause it to develop intersex flowers and flowers of the opposite sex on male and female plants. Male and female plants can form flowers of the opposite sex and bisexual ones. This shows that breeding work may use traumatic injuries and photoperiods as provocative methods revealing the degree of monoecious stability" (91, p. 8). In experiments of N.N. Grishko et al. (91), modified environmental conditions (signals) were used to control the sex of flowers and a mode of seed reproduction in hemp without any changes of sex chromosomes in its genome. Normally, hemp is obligate cross-pollinated crop producing seeds only on plants with female flowers; the impact of injury stress on plants of both sexes allowed the formation of seeds on both male and female individuals $(91,92)$. Ukrainian biologists have promoted the revolutionary advance in selection of hemp: they obtained monoecious forms capable of self-pollination, which, in turn, has led to creation of hemp varieties not containing cannabinoids and scarcely ever possible in dioecious hemp (93).

Formation of seeds in strawberry (genus Fragaria L., family Rosaceae). The genus Fragaria includes several dioecious species according to which the whole genus was assumed to produce seeds through cross-pollination. Bisexual (hermaphroditic) flowers develop only in diploid species (94); in populations of polyploid species, plants with bisexual flowers occur along with individuals having purely pistillate and purely staminate flowers (Fig. 6). Strawberry also shows multividual variation - "some largefruited strawberry varieties have in one inflorescence all the three types of flowers" (94, p. 107).
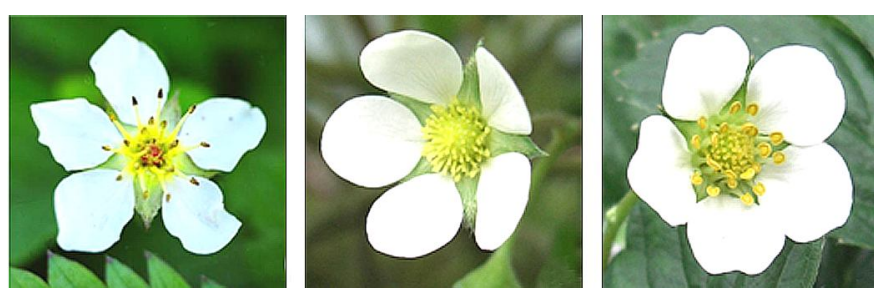

Fig. 6. Flowers of strawberry (genus Fragaria) — staminate, pistillate, and bisexual (hermaphroditic) flowers (left to right).

However, like beetroot, strawberry exhibits a switchover between sexual (gamospermic) and agamospermic mode of seed reproduction, i.e. uni- and biparental reproduction. Although autonomous parthenogenesis of strawberry hasn't been yet described, Fragaria species show induced parthenogenesis (embryogenesis caused by pollination of pistillate flowers with foreign pollen from other strawberry species or other genera of the family Rosaceae).

"In distant crosses (in Fragaria and other genera) it is frequent the occurrence of plants of maternal type with the same number of chromosomes as in a female parent. The study has shown that pollination is a necessary condition for formation of such matroclinal seedlings. According to a summary of S.S. Khokhlov, pseudogamy [induction mechanism of parthenogenesis: a sperm fertilizes the central nucleus of the embryo sac while the ovule develops parthenogenetically; pollen donor don't serve as a father parent, because there's no transfer of genes from male gamete (sperm) to the ovule 
(apozygote) - authors' note] was found in 6 of the 14 Rosaceae genera known to have apomixis" (31, p. 88). "Octaploid plants of oriental strawberry were pollinated with: pollen from diploid wild strawberry $(F$ vesca, $2 n=14)$, induced autotetraploids of wild strawberry $(F$. vesca, $2 n=28)$, diploid forest strawberry $(F$. collina, $2 n=14)$, autotetraploid forest strawberry $(\mathrm{F}$. collina, $2 \mathrm{n}=28)$, hexaploid garden strawberry $(F$. moschata, $2 n=42)$, large-fruited strawberry $(F$. ananassa, $2 n=56)$, as well as the mixture of pollen from oriental strawberry $(F$. orientalis, $2 n=28)$ and large-fruited strawberry $(2 n=16)$. In all these variants, infructescence $<\ldots .>$ of fruits and seeds was almost similar, except the variants № 20-3 $\times F$. collina $2 n$ and № $25 \times F$. collina $2 n$. In these combinations, the fruits were significantly larger than the fruits developed after free pollination. The seedlings were quite atypical for distant hybrids. Seedlings obtained through the open pollination of octaploids and crosses between them and different species exceeded the octaploid strawberry and tetraploid oriental strawberry by growth vigor and leafiness. In most of these seedlings flower stalks overtopped leaves and were more abundant than in $4 n$ and $8 n$ oriental strawberries. The seedlings exhibited higher fecundity than the original octaploids, in some cases - even exceeded $4 n$ oriental strawberry. Cytological analysis of plants grown from the seeds of the induced octaploid oriental strawberry has revealed their ploidy $2 n=28$ instead of expected $56,21,35$, 84, etc. regardless the variant of pollination. Apomixis is the only possible explanation for the occurrence of tetraploid seedlings after pollination of octaploid $F$. orientalis with pollen from various species" (31, p. 93-94). D.F. Petrov with colleagues conducted the extensive pollination experiment on autotetraploid strawberry $(F$. vesca, $2 n=28)$ using the pollen of other species with different ploidy (31). The only result of this work was the induction of development in $F$. vesca of parthenogenetic seeds, and no hybrid seeds were obtained.

In other similar pollination experiments on large-fruited strawberry $F$. ananassa L. treated with pollen from a distant relative species - silverweed (Potentila anserine L.), seed progenies resulting from pseudogamic fertilization manifested segregation for basic reproductive characters - sex of flowers and permanent flowering capacity. This means that the parthenogenetic seed progenies derived through interspecific pollination and pseudogamic fertilization developed from generative cells of embryo sacs after their meiosis. Polyploid genome of $F$. ananassa $(2 n=8 \mathrm{x}=56)$ contributed to polysomic type of segregation for marker traits $(95,96)$ similar to the case described earlier in sugar beet $(71)$.

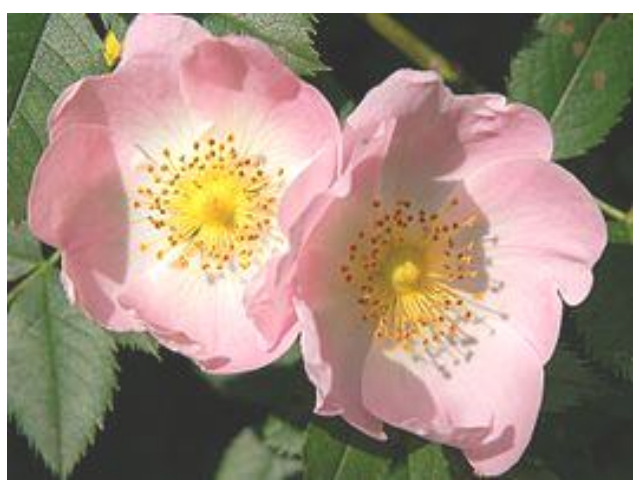

Fig. 7. Flowers of pentaploid wild rose Rosa canina producing heterogamous mega- and microspores (97).

Seed reproduction of Rosa canina L. $(2 n=5 \mathrm{x}=35$, family Rosaceae). Wild rose, or dog rose $R$. canina (Fig. 7), has odd polyploidy - it is a pentaploid species. Despite its pentaploid genome, $R$. canina produces seeds through double fertilization with unequal contributions of mother and father parents into genomic composition of progeny. $R$. canina has some unique peculiarities in formation of macro - and microspores not common to other Rosaceae, as well as other families with even number of genomes per cell.

Swedish cytogenetics A. Gustafsson, A. Hakonsson, and F. Fagerland wrote (97, 98 ) that not all chromosomes of $R$. canina are involved in meiotic division, but only 14 of 35. During conjugation, these 14 chromosomes form 7 pairs of bivalents, and conjugation of homologs in cells of maternal megaspores and paternal microspores occurs similarly. The rest of the chromosomes ( 21 of 35 ) do not participate in meiosis and, as seen in specimens, they remain univalent. Upon completion of the first meiotic division, 28 chromosomes are located on micropylar end, while the other 7 - on the other cellular pol. The second meiotic division proceeds normally and leads to linear tetrads of mega- and microspores (two cells with 28 and two - with 7 chromosomes). One of megaspores with 28 chromosomes develops into a functional embryo sac. In anthers, on the contrary, functional pollen grains develop from the cells with 7 chromosomes, while the cells with 28 chromosomes degenerate. Cross-fertilization restores pentaploid state of the genome $(2 n=5 \mathrm{x}=35)$ through merging of the ovule ( 28 chromosomes) with the sperm ( 7 chromosomes). Thus, in heterogametic species $R$. canina contributions of pollen and ovule in the genome of seed progeny amount as, respectively, 20 and $80 \%$. The literature describes similar cases of anisogamy - segmental parthenogenesis, or segmental agamospermy. Obviously, patterns of splitting and numerical ratio of genotypes for some traits in $R$. canina may be assumed as corresponding to Mendel's laws for pea (for one part of the genome) and absolutely distinct (for the other part).

Concluding the discussion about two paradigms of heredity, variation, and development, it should be noted that gene-centric paradigm of life established in the $20^{\text {th }}$ century assumes that the major source of hereditary variation in populations of plants and animals is associated mainly with mutations and recombination of genes in their genomes. G. Mendel was the first who formulated laws of inheritance of characters in plants based on his experiments with pea (Pisum sativum) in 1865. These experiments became the start point for a new science genetics that strongly influenced the development of research on heredity and variation throughout the $20^{\text {th }}$ century. Mendel's ideas of hereditary factors were expanded within the chromosome theory of T. Morgan (1915) and the discovery of the chemical code of nucleic acids by J.D. Watson and F. Crick (1953).

Meanwhile, results of Mendel's experiments (1869) with inheritance of flower color in Hieracium were essentially opposite to his findings in Pisum sativum. However, Mendel's observations of hawkweed are no less important for understanding the nature of genetic variation than experiments on pea. Variation in hybrid generations of Hieracium was associated with several factors - discrete factors of flower color in the crossed forms (like in pea), polyploidy, and available modes of seed reproduction - uniparental and biparental. It wasn't possible for Mendel to assess the whole complexity and importance of his experiments on Hieracium, but now these results are actually in line with modern studies of epigenetic inheritance and variation (99-101).

EGP is not less popular among modern biologists than GCP in the $20^{\text {th }}$ century. Experiments with various biological objects during the $20^{\text {th }}$ century have revealed a narrowness of GCP not capable to explain many facts of inheritable variation in plants and animals. For example, variation in amount of genomes in the nuclei of plant cells (polyploidy) doesn't any affect the structure and location of genes in chromosomes, but polyploid plants manifest notable differences from diploids and significant variation of any morphological, physiological, and biochemical characters.

One of the most important events in formation of EGP was the discovery of B.L. Astaurov in 1927 - the third ("asymmetric") type of variation, which was later renamed as epigenetic. The ideas of such variation probably arise from the early $19^{\text {th }}$ century and the concept of inherited acquired characters established by J.-B. Lamarck and admitted by Ch. Darwin at the close of his days.

So, the "third", or epigenetic, variation is realized in modes of seed reproduction of plants and morphogenetic processes, especially the formation of symmetry types and fractal structures (that develop through self-organization without direct genetic control). The analysis of seed reproduction in various species and genera shows that reproductive characters of plants in most cases can't be defined as Mendelian and show epigenetic inheritance. Different modes of seed reproduction in pea (double fertilization) and hawkweed (apogamy) 
reflect polymorphism of reproductive strategies in these two botanical genera not associated with to activity or inactivity of any specific "parthenogenetic" genes. In the authors' view, parthenogenetic embryogenesis in plants is the phenomenon of epigenetic variation associated with external or internal signals that induce apogamic development of cells of embryo sacs and ovules to change the program of development. Multiple modes of seed reproduction in some plant species (Beta vulgaris L., Cannabis sativa L., Rosa canina L., genus Fragaria L.) reflect both similarities and differences in their genetic systems.

The authors thank the deputy chief editor of the periodical "Biosphere" A.G. Golubev for his valuable critics and providing the links to several important works not included in the first version of the article.

\section{REFERENCES}

1. Dokinz R. Egoistichnyi gen [Selfish gene]. Moscow, 1993.

2. Lipton B. Umnyekletki: biologiyaubezhdenii. Kak myshlenie vliyaet na geny, kletki i DNK [Smart Cells: Conviction Biology. Haw the Thinking Affects Genes, Cells and DNA]. Moscow, 2011.

3. Buss L.W. Evolution, development and units of selection. PNAS USA, 1983, 80: 1387-1391.

4. Hartwell L.H., Hopfield J.J., Leibler S., Murray A.W. From molecular to modular cell biology. Nature, $1999,402: 47-52$.

5. Hurd P.J. The era of epigenetics. Brief. Funct. Genomics, 2010, 9(5-6): 425-428.

6. Dragavtsev V.A. Biosfera, 2012, 4(2): 245-256.

7. Maletskii S.I., Melent'eva S.A., Tatur I.S., Yudanova S.S., Maletskaya E.I.Vesti NAN Belarusi (seriya agrarnykh nauk), 2013,1 : 65-72.

8. Bastow R., Mylue J.S., Lister C., Lippman Z., Martienssen R.A., Dean C. Vernalization requires epigenetic silencing of FLC by histon methylation. Nature, 2004,

427: 164-167.

9. Sung S., Amasino R.M. Vernalization and epigenetics: how plants remember winter. Curr. Opin. Plant Biol., 2004, 7: 4-10.

10. Spenser G. Nasledsrvennost'. Osnovaniya biologii [Heredity. The Base of Biology]. St. Petersburg, 1870: $173-187$.

11. Rieger R., Michaelis A., Green M.M. Glossary of genetics. Classical and molecular. Berlin-Heidelberg-NY-London etc., Springer-Verlag, 1991.

12. Timiryazev K.A. Nasledstvennost' [Heredity]. Moscow, 1939: 164-195.

13. Fisher R.A. The correlation between relatives on the supposition of mendelian inheritance. Royal Society of Edinburgh, 1918, 52: $399-433$.

14. Maletskii S.I. Informatsionnyi vestnik VOGiS, 2009, 13(4): 820-852.

15. Bateson W. Mendel's principles of heredity. London, Cambridge, NY, 1909.

16. Vavilov N.I. Mendelizm i ego znachenie v biologii i agronomii. Gregor Mendel'. Opyty nad rastitel'nymi gibridami [Mendelianism and its Importance in Biology.

Gregor Mendel. Experiments on Plant Hybrids]. Moscow, 1965: 98-106.

17. Kartel' N.A., Makeeva E.N., Mezenko A.M. Genetika [Genetics]. Minsk, 2011.

18. Nogler G.A. The lesser-known Mendel: his experiments on Hieracium. Genetics, 2006, 172: 1-6.

19. Astaurov B.L. Zhurnal eksperimental'noi biologii, 1927, 3(1-2): 1-61; 3(3-4): 199-201.

20. Bogdanova E.D. Morfologicheskaya izmenchivost' pshenicy, inducirovannaya nikotinovoi kislotoi [Wheat morphogenetic variability induced by nicotinic acid]. Alma-Ata, 1984.

21. Bogdanova E.D., Makhmudova K.Kh. Epigenetika myagkoi pshenicy [Epigenetics of Soft Wheat]. Almaty, 2012.

22. Maletskii S.I. In: Plant Epigenetics. Novosibirsk, 2005: 7-54.

23. Durrant A. The environmental induction of heritable change in Linum.Heredity, 1962, 17(1): 431-439.

24. Mendel' G. Opyty nad rastitel'nymi gibridami (1865) [Experiments on Plant Hybrids (1865)]. Moscow, 1965 : 7-48.

25. Khrzhanovskii V.S. Rod yastrebinok - Hieracium. Kurs obshchei botaniki [General Botany]. Moscow, $1976: 327$.

26. Ostenfeld C.H. Experiments on the origin of species in the genus Hieracium(apogamy and hybridism). New Phytologist, 1912, 11(9): 347-354.

27. Khromosomhye chisla tsvetkovykh rastenii [Chromosome Numbers of Flowering Plants]. Leningrad, 1969: 111-114.

28. Ostenfeld C.H. Further studies on the apogamy and hybridization of the Hieracia. Zeitschrift fur Inductive Abstammungs und Vererbungsehre, 1910, 3(1): 241-285.

29. Khokhlov S.S. Uspekhi sovremennoi genetiki [Achievements in Modern Ggenetics]. Moscow, 1967, 1: 43-105.

30. Khokhlov S.S., Zaitseva M.I., Kupriyanov P.G. Vyyavlenie apomiktichnykh rastenii vo flore tsvetkovykh rastenii SSSR [Detection of Apomictic Plants in the Flora of Flowering Plants in the USSR]. Saratov, 1978.

31. Petrov D.F., Sankin L.S., Sukhareva N.B., Lukina L.A. Problemy apomiksisa u rastenii i zhivotnykh [Problems of Apomixes in Plants and Animals]. Novosibirsk, 1973: 88-95.

32. Kholodkovskii N.A. Biologicheskie ocherki [Biological Essays]. Moscow-Petrograd, 1923.

33. Maletskii S.I., Levites E.V., Baturin S.O., Yudanova S.S. Reproduktivnaya biologiya rastenii. Geneticheskii slovar' [Plant Reproductive Biology]. Novosibirsk, 2004.

34. Smith J. Notice of plant produced seeds without any apparent action of pollen. Transaction of the Linn. Society (Meeting of June 18th 1839). London, 1841: 509512 .

35. Mendel' G. Opyty nad rastitel'nymi gibridami [Experiments on Plant Hybrids]. Moscow, 1965: 57-96.

36. Rosenberg O. Cytological studies on the apogamy in Hieracium. Sv. Bot. Tidskr., 1907, 7: 918-919.

37. Petrov D.F. Apomiksis v prirode i opyte [Apomixis in Nature and in Experiments]. Novosibirsk, 1988.

38. Haldane J.R.S. Theoretical genetics of autopolyploids. J. Genet., 1930, 22: 359-372.

39. Lutkov A.N. Eksperimental'naya poliploidiya v selektsii rastenii [Experimental Polyploidy in Plant Breeding]. Novosibirsk, $1966:$ 7-34.

40. Levites E.V., Ovechkina O.N., Maletskii S.I. Genetika, 1999, 35(8): 1086-1092.

41. Hanna W.W. Use of apomixes in cultivar development. Adv. Agronomy, 1995, 54: 333-350.

42. Kindiger B., Sokolov V. Progress in the development of apomictic maize.Trends in Agronomy, 1997, 7: 75-94.

43. Savidan Y. Apomixis and agamic complex: from theory to practice. Species complex, gene flow and plant genetic resources. Paris, 1992: 291-300.

44. Petrov D.F. Geneticheskie osnovy apomiksisa [Genetic Basis of Apomixis].Novosibirsk, 1979.

45. Richards A.J. Agamospermy. Plant breeding system. London-Weinheim-NY-Melburne-Madras, 1997: $396-450$.

46. Klimenko V.V. Biologiya v shkole, 2006, 4: 3-12; 7: 3-7.

47. Filipchenko Yu.A. Izmenchivost' i metody ee izucheniya. Osnovy biologicheskoi variatsionnoi statistiki [Variability and Method for its Study. A Basis of Variation Statistics]. Leningrad, 1926: 5-32.

48. Kekser G. Modelirovanie v biologii [Modeling in Biology]. Moscow, 1963: 42-64.

49. Batygina T.B. Teoreticheskie osnovy reproduktsii rastenii. Ot mikrospory k sortu [Theoretical Basis of Plant Reproduction. From Microspores to Plant Vari-

ety]. Moscow, 2010: 12-74.

50. Dragavtsev V.A., Lutin P.P., Shkel' N.M., Nechiporenko N.N. DAN SSSR, 1984, 274(3): 720-723.

51. Yablonka E., Lemb M. Vistnik Ukr. tov. genetikiv i selektsioneriv, 2008, 6(2): 337-355.

52. Savel'ev S.V. Izmenchivost' $i$ genial'nost' [Variability and Genius]. Moscow, 2012.

53. Golubovskii M.D. Vek genetiki: evolyutsiya idei i ponyatii. Nauchno-istoricheskii ocherk [A Century of Genetics: Evolution of Ideas and Concepts]. St. Petersburg, 2000 .

54. Astaurov B.L. Issledovanie nasledstvennikh narushenii bilateral'noi simmetrii v svyazi s izmenchivost'yu odinakovykh struktur v predelakh organizma. Nasledsvennost' i razvitie [Study of Inherited Disorders in Bilateral Symmetry as Related to Variability of Identical Structures in Organism. Heredity and Development]. Moscow, 1974: 54-109.

55. Babkov V.V. Moskovskaya shkola evolyutsionnoi genetiki [The Moscow School of Thought on Evolutionary Genetics]. Moscow, 1985 : 59-72.

56. Strunnikov V.A., Vyshinskii I.M. Problemy genetiki i teoriya evolyutsii [Problems of Genetics and Evolution]. Novosibirsk, 1991 : $99-114$.

57. Vasil'ev A.G., Vasil'eva I.A., Bol'shakov V.N. Fenologicheskaya izmenchivost' $i$ metody ee izucheniya [Phenogenetic Variability and Methods for its Study].

Ekaterinburg, 2007: 8-18. 
58. Golubev A.G. Genes at work in random bouts. Prospects \& Overviews. Bioessays, 2012, 34: 311-319.

59. Urmantsev Yu.A. Simmetriya prirody i priroda simmetrii [Symmetry of Nature and the Nature of Symmetry]. Moscow, 1974.

60. Riger R., Mikhaelis A. Geneticheskii i tsitologicheskii slovar' [Genetic and Cytological Dictionary]. Moscow, 1967.

61. Iogannsen V. Elementy tochnogo ucheniya ob izmenchivosti i nasledstvennosti s osnovami biologicheskoi variatsionnoi statistiki [Elements of the Precise Doctrine for Variability and Heredity with the Basics of Variation Statistics]. Leningrad, 1933.

62. Timofeev-Resovskii N.V. Zhurn. eksp. biol. (ser. A), 1925, 1(3-4): 93-142.

63. Arinshtein A.I. Nasledstvennost' i izmenchivost' rastenii, zhivotnikh i mikroorganizmov. Tom 2 [Heredity and Variability in Plants, Animals and Microorganisms.

Vol. 2]. Moscow, 1959: 104-110.

64. Strunnikov V.A. Priroda, 1989, 2: 17-27.

65. Turing A.M. The chemical basis of morphogenesis. Philosophical Transactions of the Royal Society of London, 1952, 237(641): 37-72.

66. Mandel'brot B. Frektal'naya geometriya prirody [Fractal Geometry in Nature]. Moscow-Izhevsk, 2002.

67. Maletskii S.I., Denisova E.V., Lutkov A.N. Genetika, 1970, 6: 180-184.

68. Holliday R., Pugh J.D. DNA modification mechanisms and gene activity during development. Science, 1975, 187: $226-232$.

69. Urbanska K.M. Pollen, mating and paternity in agamospermous angiosperms. Plant Species Biology, $1994,9: 57-67$.

70. Roik N.V., Koval'chuk N.S., Yatseva O.A., Maletskii S.I. Sakharnaya svekla, 2012, 9: 85-93.

71. Maletskii S.I., Maletskaya E.I., Yudanova S.S. Vavilovskii zhurnal genetiki i selektsii, 2011, 15(1): 66-80.

72. Achard F.C. Ausfürliche Beschreibung der Methode nach welcher bei der Kultur der Runkelrübe verfahren werden muß, um ihren Zuckerstoff nach Möglichkeit zu vermehren: Reprint. Berlin, Academie-Verlag, 1984, Bd. 63.

73. Zaikovskaya N.E. Biologiya i selektsiya sakharnoi svekly. Moscow, 1968: 137-207.

74. Kharchenko-Savitskaya E.I. Tsitologiya i embriologiya sakharnoi svekly. Tom 1. Sveklovodstvo [Cytology and Embryology of Sugar Beet. V. 1. Beet]. Kiev, 1940: 453-550.

75. Kharchenko-Savitskaya E.I. Doklady AN SSSR, 1938, 18: 469-474.

76. Oldemeyer R.K., Smith P.B. Importance of sugar beet hybrid development. J. Int. Inst. Res. Beet, 1965, 1: 16-27.

77. Favorskii N.V. Trudy nauchnogo instituta selektsii, vypusk II (Kiev), 1928: 3-11.

78. Shiryaeva E.I., Yarmolyuk G.I., Kulik A.G. In: Tsitogeneticheskie i tsitoembriologicheskie issledovaniya v selektsii sakharnoi svekly. Kiev, $1988:$ 28-38.

79. Shiryaeva E.I., Yarmolyuk G.I., Kulik A.G., Chervyakova V.A. Tsitologiya i genetika, 1989, 24(3): 39-44.

80. Seilova L.B. Apomoksis u sakharnoi svekly i ego ispol'zovanie v prakticheskoi selektsii [Apomixis sugar beet and its use in practical breeding]. Almaty, 1996.

81. Seilova L.B. In: Entsiklopediya roda: biologiya, genetika i selektsiya svekly. Novosibirsk, 2010: 158-163.

82. Bogomolov M.A. In: Entsiklopediya roda: biologiya, genetika i selektsiya svekly. Novosibirsk, 2010: $504-513$.

83. Maletskii S.I., Maletskaya E.I. Genetika, 1996, 32(12): 1643-1650.

84. Maletskii S.I. Binomial'nye raspredeleniya v geneticheskikh issledovaniyakh na rasteniyakh. Novosibirsk, 2000.

85. Yudanova S.S., Maletskaya E.I. In: Dosyagnennya i problemi genetiki. selektsii ta biotekhnologii. Kiev, 2007, tom 2: $221-225$.

86. Tsil'ke R.A., Poznyak S.I., Maletskaya E.I., Yudanova S.S., Maletskii S.I.Vestnik NGAU (Novosibirsk), $2010,5(3)$ : 19-25.

87. Levites E.V., Maletskii S.I. Genetika, 1999, 35(7): 939-948.

88. Levites E.V., Shakhova I.S., Kirikovich S.S. Povtornyi tsikl yarovizatsii i tsveteniya kak faktor epigeneticheskoi izmenchivosti u sakharnoi svekly[Recycled Vernalization and Flowering as Factors of Epigenetic Variability in Sugar Beet]. Novosibirsk, 2001.

89. Levites E.V., Shkutnik T., Ovechkina O.N., Maletskyi S.I. Doklady RAN, 1998, 362(3): 430-432

90. Roik N.V., Koval'chuk N.S., Yatseva O.A., Maletskii S.I. Vistnik agrarnoi nauki UAAN (Kiev), 2012, $10: 42-48$.

91. Grishko N.N. Doklady VASKHNIL, 1935, 3(1): 5-14.

92. Grishko N.N., Delone L.N. Kurs genetiki [Genetics]. Moscow, 1938.

93. Virivits V.G., Laiko I.M., Sitnik V.P. i dr. Faktori eksperimental'noi evilyutsii organizmiv [The Factors of Experimental Evolution of Organisms]. Kiev, 2006, tom 3: $18-22$.

94. Fedorova N.Ya. Sotsialisticheskoe rastenievodstvo, 1935, 15: 101-110.

95. Baturin S.O., Sukhareva N.B., Maletskii S.I. Genetika, 1995, 31(10): 1418-1424.

96. Maletskii S.I., Sukhareva N.B., Baturin S.O. Genetika, 1994, 30(2): 237-243.

97. Fagerland F. Die bastarde der Canina rosen, ihre Syndese und Formbildungsverhaltnisse. Act. Hort. Berg., 1945, 14 : 9-37.

98. Gustafsson A., Hakonsson A. Meiosis in some rose hybrids. Botanical Naturalist, 1942: 331-342.

99. Thomas P.T. Reproductive versatility in Rubus. II. The chromosome and development. J. Genet., 1940, 40: 119-128.

100. Roik N.V., Koval'chuk N.S., Yatseva O.A. Vistnik agrarnoi nauki UAAN(Kiev), 2010, 9: 19-22.

101. Kunakh V.A. Zherbakovskie chteniya III [Proc. 3d Zhebrakov's Scientific meeting]. Minsk, 2011. 